\title{
Article \\ Community Perception and Attitude towards Sustainable Tourism and Environmental Protection Measures: An Exploratory Study in Muscat, Oman
}

\author{
Anitha Ravikumar*(D), Sheikha Al Subhi and Krishna Murthy Meesala
}

Citation: Ravikumar, Anitha,

Sheikha Al Subhi, and Krishna

Murthy Meesala. 2022. Community

Perception and Attitude towards

Sustainable Tourism and

Environmental Protection Measures:

An Exploratory Study in Muscat,

Oman. Economies 10: 29. https://

doi.org/10.3390/economies10020029

Academic Editor: Angeliki

N. Menegaki

Received: 11 December 2021

Accepted: 13 January 2022

Published: 20 January 2022

Publisher's Note: MDPI stays neutral with regard to jurisdictional claims in published maps and institutional affiliations.

Copyright: (C) 2022 by the authors. Licensee MDPI, Basel, Switzerland. This article is an open access article distributed under the terms and conditions of the Creative Commons Attribution (CC BY) license (https:// creativecommons.org/licenses/by/ $4.0 /)$.

\author{
Department of Business Studies, University of Technology and Applied Sciences (HCT), Muscat 133, Oman; \\ sheikha.alsubhi@hct.edu.om (S.A.S.); krishna.murthy@hct.edu.om (K.M.M.) \\ * Correspondence: anitha.ravikumar@hct.edu.om
}

\begin{abstract}
Sustainable tourism supports a great level of tourist contentment and assures a significant experience for the visitors, realizes the importance of sustainability issues and encourages sustainable tourism practices and customs among them. Long-term success in tourism is possible only with the support of the local residents. Earlier research supports the significance of local population backing in order to make tourism more sustainable. As a result, it is necessary to comprehend the attitudes and perception of the local people, which will provide a treasured acquaintance for numerous tourism improvement programs. The present study was conducted in Muscat, Sultanate of Oman, to understand the community perception on tourism impact and environmental protection measures taken by the government. The study indicates that the local community is aware of the benefits of tourism development. The government should take steps to create awareness about the need for public support for the preservation of heritage sites. They should also be provided information about how the local community can benefit by way of job opportunities, small businesses, etc.
\end{abstract}

Keywords: keyword; perception; attitude; economic; socio-cultural; environment and sustainable tourism

\section{Introduction}

UNWTO (2020) describes sustainable tourism as tourism that considers both current and future economic, social and environmental effects and meets the needs of the visitors, the industry, the environment and the local people. The involvement of all related stakeholders is needed for holistic sustainable tourism development. Achieving sustainable tourism is a constant process, and it comprises of the uninterrupted examining of consequences, instigating the expected safety and/or curative procedures.

Day-to-day human activities worsen the natural environment coupled with the substantial growth of tourism. Development of tourism is imperiling the environment and extinguishing the environmental resources as well. Travel by road and air discharges gases such as carbon dioxide, which escalates global temperature. Apart from that, tourism creates and raises wastes. The above apprehensions can be tackled, and tourism can be sustained if the knowledge of environment friendliness is formed amongst the travelers (Stefanica and Butnaru 2015).

Sustainable tourism supports a great level of tourist contentment and assures a significant experience for the visitors, realizes the importance of sustainability issues and encourages sustainable tourism practices and customs among them.

Other Arab nations confronted a lot of harmful impacts when the tourism sector was developed. The Sultanate of Oman is conscious of the undesirable effects of other Arab nations and is perceptive to evade gaffes. Ministry of tourism is far-reaching in welcoming the travelers who can appreciate and uphold its different natural resources and protect traditional customs and distinctive delights of archaeology (Mershen 2007). The Sultanate 
of Oman's Ministry of Tourism is tenacious on the concept of sustainable tourism to protect the environment and to have a reduced effect on the adverse impact of mass tourism (Oman Tourism 2015).

The management of natural and human-made assets is extremely essential for the sustainability of the tourism sector. Developments that harshly distress the environment, i.e., are short-term, have an enormous volume and are deceitful in nature should be shirked. Noteworthy qualities of a sustainable tourism strategy encompass the usage of land, managing the physical environment, safeguarding natural and cultural traditional locations, enhancing market-led products and outlaying human assets (Baporikar 2012).

The Sultanate of Oman's another goal is protecting the architecture of the country along with preserving the environment and cultural heritage. Culture and heritage are vital for the nation and must not be let to ruin even in a minor percentage. The government of Oman has made guidelines in order to make sure tourists abide by the regulations. The Ministry of Housing, Ministry of Tourism and Ministry of Environment and Climate affairs have given various instructions to conserve the environment, such as the colors, designs and materials used in buildings. Due to the guidelines, the beauty of the environment is preserved with no damage (Prabhu 2015).

The Sultanate of Oman possesses numerous heritage sites in various parts of the nation and comprises massive prospects to improve the tourism sector. Visitors would be exultant if such vital places are conserved and fulfill the needs of the travelers without destroying the heritage, ideals and traditional facets. It is significant that the opinion of the tourists and backing of the community is deliberated as a device to gauge and develop the heritage transformation (Al-Hashim 2015).

Both positive and negative impacts are created by the tourism sector on the local community. Increased economic activities, jobs and improved social services create a positive impact while a negative impact is created due to stress or damage on indigenous resources and cultural values. The local community's contentment is central for sustainable tourism. Data also confirms that in certain risky circumstances, the umbrage of local people has propelled travelers away. Hence, it is vital for the tourism sector to uphold a positive relationship between the residents and visitors to avoid any adverse consequences (UNWTO 2020).

Tourism studies have received close attention due to the real and evident socioeconomic contribution to local communities (Lindberg and Rebecca 1997). The world is facing an inexplicable health, economic and social disaster due to COVID-19. The tourism industry is one of the worst affected industries, with travel restrictions, hotels shut and flights grounded in almost all the countries (UNWTO 2020).

According to Hilsenrath (2020), globalization is the major reason for the spread of COVID-19, while tourism aggravates the situation. As travelling from one country to another is restricted, governments of various countries are focusing on inbound tourism. Inbound tourism can affect the socio-economic welfare of the local community in tourism destinations. During the pandemic, the negative impacts may worsen. In such a situation, the local community's support is vital.

Long-term success in tourism is possible only with the support of the local residents. Earlier research support the significance of the local population's backing in order to make tourism more sustainable. As a result, it is necessary to comprehend the attitudes and perceptions of the local people, which will provide treasured acquaintances for numerous tourism improvement programs. According to Chandralal (2010) and Al-Hashim (2015), the local community's support for heritage preservation and for tourism development is imperative. Tourism development is not possible without community participation and the observation and attitude of local public towards tourism provides useful knowledge that will aid the government in taking necessary steps to generate awareness to improve tourism. Kaplan (2015) advocates that the perception of the community is essential to understand and evaluate the development and growth of tourism in a country. The exclusion of the 
residents of a country results in the omission of main stakeholders in the sustainable tourism sector, which contributes to economic development.

Therefore, this study was conducted to scrutinize the community perception on the economic, socio-cultural and environmental aspects of sustainable tourism. Moreover, an attempt was also made to examine the local community's perception on the measures taken to protect the environment due to tourism activities.

\section{Review of Literature}

According to Healey (1998), we can achieve three goals, namely stability and harmony, reduction in conflicts and rise in awareness and negotiation and containment through community participation. To implement collaborative approaches, involving the stakeholders in policy development regarding the quality of destinations and its delivery; broadening the stakeholder involvement beyond the powerful rich; acknowledging the various forms of indigenous knowledge and creating rich community networks as a means of institutional capital with new proposals can be implemented quickly and lawfully. These views are supported by Dola and Dolbani (2006) in their article, which says that the journey of sustainable development without quality community participation may yield negative results. There are several barriers, which hinder efficient quality participation. The barriers include the inability to persuade more people to participate and get a quality opinion, a lack of knowledge and awareness among the public regarding the significance of participation and the absence of an authority's attempt to communicate. In order to increase the participation and to reduce the barriers as well as to support the public in developing their confidence and skills, the reformation of the participation process, giving importance to a developing public capacity for participation by training and other approaches must be carried out.

Community views are important for effective sustainable tourism development, as the understanding of communities' feelings and thoughts could be useful to the decision makers. Community participation is more important, as they effect the tourism development either constructively or destructively (Eshliki and Mahdi 2012).

Bakshi and Gupta (2016) have found that a local community tends to participate in tourism development only if they have realized that there is optimistic economic impact. Further, the attitude is based on the awareness level of the community regarding tourism development. Majority of the attitude is due to the economic impact, and social impact plays a role in framing the attitude of the local population. There is a direct impact of attitude towards tourism development and participation in tourism development.

Community participation is essential for regaining and sustaining the world heritage sites, which helps in the economic development and consequent development in the standard of living of the local communities. Without the support of local communities, it will be difficult to attract tourists, and hence will be difficult to increase the span of economic benefits (Rasoolimanesh and Mastura 2016).

The tourism industry must work with a pensiveness to ecology and initiate ecotourism and green hotels. Hence, the local inhabitants are the important stakeholders in the development and conservation of a successful tourism progress, as incessant community involvement and informative programs at all levels that explicate the importance of tourism to the environment and economy are essential (Tsaur and Wang 2007). Tourism is one of the important players in economic growth (Kandampully 2000). Tourism not only contributes to economic growth but also to revenue creation, employment opportunities and aid for the development of regional wealth. Tourism contributes to the foreign exchange of a country and develops the local economy (Sirakaya et al. 2001). Sustainable tourism is an important objective of any country, and consists of various forms of activities, namely ecotourism activities, green tourism activities and geo-tourism activities. Sustainable tourism is referred to as the tourism activity that promotes economic development that integrates the requirements to enhance various prospects for the future (McIntyre et al. 1993). Tourism industry is one where the investor earns a huge revenue with less investment 
by adding economic growth, which encourages large number of people to be involved in this industry (UNWTO 2021).

Sustainable tourism provides great exposure to the visitors in providing an unusual experience that enhances the quality of the providing country. The tourism experience results in a positive vibration and adds to the value of the natural environment. It was concluded that sustainable tourism helps to reduce the negative vibrations on society and on the natural atmosphere at the same time by providing benefits to the residents and citizens (McIntyre et al. 1993). Planning for sustainable tourism in a society consists of concentrating on huge stakeholders in the society, who seek collaborative strategies, vigorous strategies, elastic strategies, and result focus-oriented strategies in different criterions, namely at the local level, regional level and national level (Sharpley 2000; Gunn 1994; Jamieson and Jamal 1997; Sirakaya 1997; Sirakaya et al. 2008).

Sustainable tourism and stakeholder contribution are one and same and never to be read differently (Murphy 1985; Ap 1992); and Gunn (1994) argued that a society that includes residents would have huge contributors to the tourism sector, as they affect the overall sector of tourism irrespective of the nature of the jobs they possess. The residents are considered the deciders of the tourism sector in general and influence the satisfaction level of the visitors (Cooke 1982; Davis et al. 1988). The residents of a nation are crucial contributors for the development, planning and growth (Hall 1994; Jamal and Getz 1995; Joppe 1996; Murphy 1985). According to Sirakaya et al. (2008), sustainable tourism helps the authorities for policymaking and managers who are responsible for the destination for identifying the benefits as well as the issues due to residents' behavior. It is found that the ability to understand the behavior of the residents on sustainable tourism leads to economic development.

In the recent past, various scholars who frequently carry out research on sustainable tourism have undertaken studies to understand the behavior of the residents (Ap and Crompton 1998; Davis et al. 1988; Delamere 1998; Godfrey 1998).

The Coronavirus pandemic has annulled the gains received from tourism over many years. Substantial job losses in the tourism sector have posed an undesirable economic impact on the citizens who rely on tourism for their living (Al-Hasni 2021). Hence, it is necessary for the local people to participate in the revival and development of the tourism sector.

\section{Methodology}

The present study was conducted in Muscat, Sultanate of Oman, to understand the community perception on tourism impact and environmental protection measures. According to Kutty (2021), Lonely Planet has named the Sultanate of Oman one of the world's must-visit countries in 2022. Oman is the only country in the Arab peninsula to be included in the list. Muscat, which is the capital city of Oman, attracts many tourists around the world and is named as the sixth best city to visit by a capital cities index. With modern architecture and ancient heritage, this city attracts a huge number of visitors. When borders open up, capital cities are the ones that will attract more tourists. Therefore, this study was conducted in Muscat, the capital city of Oman. Secondary data for the study were collected from various websites, journals, newspapers, etc. Secondary data was collected by preparing a structured questionnaire. The questionnaire was divided into two parts. The first part consisted of demographic profile of respondents such as age, gender and educational levels. The second part consisted of 22 questions related to tourism impact and environmental protection measures. The questionnaire was prepared both in English and Arabic versions. Both versions of the questionnaire were uploaded in Google forms separately in different links. Both links were shared with the respondents through friends, relatives and colleagues. We were able to collect 388 responses from the residents of Oman. The data collected was analyzed with the help of factor analysis, and only those items which were fit for the study were retained; the remaining were excluded from the study. To 
find out whether the questionnaire used is reliable or not, factor analysis was conducted using SPSS 16.0.

\section{Results}

Table 1 shows the demographic profile of respondents. Majority of the respondents are female between the age group of 18 and 32 years with a bachelor's degree. Out of 388 respondents, 224 respondents belong to the age group of 18 to 32 years.

Table 1. Demographic profile of respondents.

\begin{tabular}{|c|c|}
\hline Variables & Total Numbers \\
\hline Sample size & 388 \\
\hline \multicolumn{2}{|l|}{ Gender } \\
\hline Male & 172 \\
\hline Female & 216 \\
\hline \multicolumn{2}{|l|}{ Age } \\
\hline 18 to 32 years & 224 \\
\hline 33 to 44 years & 83 \\
\hline 45 to 53 years & 53 \\
\hline 54 to 60 years & 20 \\
\hline 61 and above & 8 \\
\hline \multicolumn{2}{|l|}{ Educational level } \\
\hline Diploma & 100 \\
\hline Bachelor's & 187 \\
\hline Master's & 39 \\
\hline Doctorate & 32 \\
\hline No formal education & 2 \\
\hline High school & 28 \\
\hline
\end{tabular}

\subsection{Exploratory Factor Analysis}

Exploratory factor Analysis was conducted to determine whether the scale used for measuring the community perception on tourism impact and measures taken to protect the environment is reliable or not. In order to conduct factor analysis, certain factors such as sample size and the sphericity of data were used. A KMO test was conducted to check whether the sample was adequate to conduct factor analysis. Table 2 shows the KMO and Bartlette's test. Hair et al. (2010) recommends a KMO measure 0.6 or above. The KMO's overall measure of 0.825 was higher than 0.6 , proving that factor analysis was suitable for the data. Hair et al. (2010) indicated that Bartlett's test of sphericity should be less than 0.05 to assume the factorability of the correlation matrix. Our results showed a high statistical significance of $(p<0.05)$. As both the tests proved that factor analysis could be conducted, exploratory factor analysis was conducted using principal factor analysis and varimax rotation.

Table 2. KMO and Bartlett's Test.

\begin{tabular}{lcc}
\hline \multicolumn{2}{c}{ Kaiser-Meyer-Olkin Measure of Sampling Adequacy } & 0.825 \\
\hline \multirow{3}{*}{ Bartlett's Test of Sphericity } & Approx. Chi-Square & 2178.046 \\
\cline { 2 - 3 } & df & 153 \\
\cline { 2 - 3 } & Sig. & 0.000 \\
\hline
\end{tabular}


Table 3 explains the Principal component analysis. Factor analysis (principal component analysis) was conducted with 22 items (Refer to Appendix A which contains the questionnaire related to tourism with 22 items). The minimum cut off point for factor loading for this study was 0.45 . After conducting principal factor analysis, items with loading of less than 0.45 was removed, and finally 17 items with a factor loading of more than 0.45 were retained. After the removal, factor analysis was conducted, and the authors were able to extract four factors with a total variance of $57.464 \%$. The first factor explained a variance of 26.147 with five items, the second factor had a variance of 13.691 with six items, the third factor had a variance of 10.682 and four items and the fourth factor explained a variance of $6.940 \%$ with three items. The first factor was named economic impact, the second factor socio-cultural impact, the third factor environmental impact and the fourth factor environmental protection measures.

Table 3. Principal component analysis (PCA).

\begin{tabular}{|c|c|c|c|c|}
\hline Eigen Value & Variance $\%$ & Factor & Item & Factor Loadings \\
\hline \multirow{5}{*}{4.446} & \multirow{5}{*}{26.147} & \multirow{5}{*}{$\begin{array}{l}\text { Economic } \\
\text { impact }\end{array}$} & Tourism creates new job opportunities & 0.796 \\
\hline & & & $\begin{array}{l}\text { Tourism provides opportunities to develop new local } \\
\text { businesses }\end{array}$ & 0.795 \\
\hline & & & Tourism brings in more investment & 0.755 \\
\hline & & & $\begin{array}{l}\text { Tourism has increased revenues of local people and } \\
\text { economy }\end{array}$ & 0.637 \\
\hline & & & Tourism helps in creating new local entrepreneurs & 0.643 \\
\hline \multirow{6}{*}{2.327} & \multirow{6}{*}{13.691} & \multirow{6}{*}{$\begin{array}{l}\text { Socio-cultural } \\
\text { impact }\end{array}$} & Places in Oman attract many foreign tourists & 0.504 \\
\hline & & & Tourism helps to preserve local cultural activities & 0.534 \\
\hline & & & Able to meet people of different cultures and traditions & 0.779 \\
\hline & & & $\begin{array}{l}\text { Tourism causes change in the traditional culture } \\
\text { among the local people }\end{array}$ & 0.739 \\
\hline & & & $\begin{array}{c}\text { Tourism has improved the quality of life of local } \\
\text { community }\end{array}$ & 0.653 \\
\hline & & & Tourism improves the quality of education & 0.665 \\
\hline \multirow{3}{*}{1.816} & \multirow{3}{*}{10.682} & \multirow{3}{*}{$\begin{array}{l}\text { Environmental } \\
\text { impact }\end{array}$} & $\begin{array}{l}\text { Tourism development destroys the local peaceful } \\
\text { atmosphere }\end{array}$ & 0.504 \\
\hline & & & $\begin{array}{l}\text { Tourism development reduces the quality of the local } \\
\text { environment }\end{array}$ & 0.847 \\
\hline & & & $\begin{array}{l}\text { Littering of wastes spoils the natural environment, } \\
\text { water ways, etc. }\end{array}$ & 0.461 \\
\hline \multirow{3}{*}{1.180} & \multirow{3}{*}{6.940} & \multirow{3}{*}{$\begin{array}{l}\text { Environmental } \\
\text { protection } \\
\text { measures }\end{array}$} & $\begin{array}{l}\text { Public places have information and guidance to } \\
\text { visitors regarding environmental protection }\end{array}$ & 0.764 \\
\hline & & & Fines are applied to those who harm the environment & 0.802 \\
\hline & & & $\begin{array}{c}\text { Government pays good attention to protect } \\
\text { environment in Oman }\end{array}$ & 0.721 \\
\hline
\end{tabular}

Total variance (\%) 57.464

Source: Authors' Calculation based on primary data.

\subsection{Community Perception on Tourism Impact and Environmental Protection Measures}

Table 4 provides the descriptive analysis of the community perception of sustainable tourism and environmental protection measures.

The local community perceived a very positive economic impact, with mean values ranging from 4.10 to 4.45 . People think that tourism helps to preserve local cultural activities with a mean value of 4.05 . They also agree that tourism causes other socio-cultural changes, 
with mean values ranging from 3.46 to 3.99. People in Oman think that even though there is a negative environmental impact from tourism, they do not strongly believe that tourism will have severe adverse impacts. This is proved with the environmental impact mean value, which is less than four, ranging from 3.4 to 3.83. They also agree that environmental protection measures are not strong enough in preserving the environment.

Table 4. Descriptive analysis of community perception of sustainable tourism and environmental protection measures.

\begin{tabular}{|c|c|c|}
\hline Items & Mean & Std. Deviation \\
\hline \multicolumn{3}{|l|}{ Economic impact } \\
\hline Tourism creates new job opportunities & 4.39 & 0.698 \\
\hline Tourism provides opportunities to develop new local businesses & 4.43 & 0.695 \\
\hline Tourism brings in more investment & 4.45 & 0.719 \\
\hline Tourism has increased revenues of local people and economy & 4.10 & 0.846 \\
\hline Tourism helps in creating new local entrepreneurs & 4.18 & 0.777 \\
\hline \multicolumn{3}{|l|}{ Socio-cultural impact } \\
\hline Places in Oman attract many foreign tourists & 3.95 & 0.958 \\
\hline Tourism helps to preserve local cultural activities & 4.05 & 0.838 \\
\hline Able to meet people of different cultures and traditions & 3.99 & 1.010 \\
\hline $\begin{array}{l}\text { Tourism causes change in the traditional culture among the } \\
\text { local people }\end{array}$ & 3.97 & 0.948 \\
\hline Tourism has improved the quality of life of the local community & 3.75 & 0.983 \\
\hline Tourism has improved the quality of education & 3.46 & 1.042 \\
\hline \multicolumn{3}{|l|}{ Environmental impact } \\
\hline Tourism development destroys local peaceful atmosphere & 3.40 & 1.056 \\
\hline Tourism development reduces the quality of the local environment & 3.52 & 1.038 \\
\hline Littering of wastes spoils the natural environment, water ways, etc. & 3.83 & 0.886 \\
\hline \multicolumn{3}{|l|}{ Environmental protection measures } \\
\hline $\begin{array}{l}\text { Public places have information and guidance for visitors regarding } \\
\text { environmental protection }\end{array}$ & 3.65 & 1.023 \\
\hline Fines are applied to those who harm the environment & 3.92 & 0.919 \\
\hline Government pays good attention to protect environment in Oman & 3.67 & 1.006 \\
\hline
\end{tabular}

\subsection{ANOVA Test Results}

ANOVA test was conducted to find out the significant differences among the demographic variables and the community perception and awareness level of respondents with the following hypotheses.

Hypothesis 1. There are no significant differences among age groups with respect to economic, socio-cultural and environmental impact.

Table 5 displays the ANOVA for significant differences among age groups with respect to economic, socio-cultural and environmental impact. The $p$-value of socio-cultural impact and environmental impact is less than $1 \%$, and the $p$-value of economic impact is less than $5 \%$ since the null hypothesis is rejected at $1 \%$ and $5 \%$. It means that there is a significant difference among the age groups. These findings are supported by Almeida-Garcia et al. (2016), which found significant differences among age groups with respect to economic, socio-cultural and environmental impact. According to the study, young people have 
a better attitude towards the economic impact of tourism, whereas older people have a negative attitude towards the economic impact of tourism. In our study, additionally, people above the age of 61 do not have a positive attitude towards economic impact.

Table 5. ANOVA for significant differences among age groups with respect to economic, socio-cultural and environmental impact.

\begin{tabular}{|c|c|c|c|c|c|}
\hline Tourism Impact & Age Groups & Mean & Std. Deviation & $F$-Value & $p$-Value \\
\hline \multirow{6}{*}{ Economic impact } & 18 to 32 years & 4.2003 & 0.51147 & \multirow{6}{*}{3.019} & \multirow{6}{*}{$0.018^{* *}$} \\
\hline & 33 to 44 years & 4.3027 & 0.44650 & & \\
\hline & 45 to 53 years & 4.1792 & 0.53231 & & \\
\hline & 54 to 60 years & 4.3438 & 0.73435 & & \\
\hline & 61 and above & 3.6875 & 0.87372 & & \\
\hline & Total & 4.2162 & 0.52906 & & \\
\hline \multirow{6}{*}{$\begin{array}{l}\text { Socio-cultural } \\
\text { impact }\end{array}$} & 18 to 32 years & 3.7557 & 0.53556 & \multirow{6}{*}{6.944} & \multirow{6}{*}{$<0.001$ * } \\
\hline & 33 to 44 years & 3.4768 & 0.83427 & & \\
\hline & 45 to 53 years & 3.2830 & 0.80006 & & \\
\hline & 54 to 60 years & 3.5000 & 0.72917 & & \\
\hline & 61 and above & 3.7143 & 0.74427 & & \\
\hline & Total & 3.6175 & 0.68295 & & \\
\hline \multirow{6}{*}{$\begin{array}{l}\text { Environmental } \\
\text { impact }\end{array}$} & 18 to 32 years & 3.5982 & 0.63078 & \multirow{6}{*}{3.627} & \multirow{6}{*}{$0.006^{*}$} \\
\hline & 33 to 44 years & 3.8635 & 0.52002 & & \\
\hline & 45 to 53 years & 3.8365 & 0.66224 & & \\
\hline & 54 to 60 years & 3.6917 & 0.66507 & & \\
\hline & 61 and above & 3.7708 & 0.81619 & & \\
\hline & Total & 3.6959 & 0.62740 & & \\
\hline
\end{tabular}

Our research results show significant differences among age groups, which finds support from Almeida-Garcia et al. (2016), who also found significant differences in age with respect to environmental impact. The findings of our study also show significant differences among age groups with regard to socio-cultural impact, which is supported by Almeida-Garcia et al. (2016)'s findings, which show that there are significant differences among age groups with regard to socio-cultural impact.

Hypothesis 2. There are no significant differences among gender with respect to economic, sociocultural and environmental impact.

Table 6 demonstrates ANOVA for significant differences among gender with respect to economic, socio-cultural and environmental impact. As the $p$-value is less than $1 \%$ with respect to economic impact, the null hypothesis is rejected at the $1 \%$ level. This means that there are significant differences between males and females with regard to economic impact. The $p$-values of socio-cultural impact and environmental impact is more than the $5 \%$ level, so the null hypothesis is accepted, and it is concluded that there are no significant differences among people of different genders with respect to the sociocultural and environmental impact. These findings are in contrast to Swain (1995), who found that male and female respondents differ significantly in their perception of tourism development. 
Table 6. ANOVA for significant differences among gender with respect to economic, socio-cultural and environmental impact.

\begin{tabular}{|c|c|c|c|c|c|}
\hline Tourism Impact & Gender & Mean & Std. Deviation & F-Value & $p$-Value \\
\hline \multirow{3}{*}{ Economic impact } & Male & 4.1068 & 0.59461 & \multirow{3}{*}{13.627} & \multirow{3}{*}{$<0.001$ * } \\
\hline & Female & 4.3032 & 0.45325 & & \\
\hline & Total & 4.2162 & 0.52906 & & \\
\hline \multirow{3}{*}{$\begin{array}{l}\text { Socio-cultural } \\
\text { impact }\end{array}$} & Male & 3.6836 & 0.69635 & \multirow{3}{*}{2.909} & \multirow{3}{*}{0.089} \\
\hline & Female & 3.5648 & 0.66903 & & \\
\hline & Total & 3.6175 & 0.68295 & & \\
\hline \multirow{3}{*}{$\begin{array}{l}\text { Environmental } \\
\text { impact }\end{array}$} & Male & 3.7345 & 0.65431 & \multirow{3}{*}{1.171} & \multirow{3}{*}{0.280} \\
\hline & Female & 3.6651 & 0.60489 & & \\
\hline & Total & 3.6959 & 0.62740 & & \\
\hline
\end{tabular}

Source: Authors' Calculation (Primary data), ${ }^{*}$-Significant at $1 \%$ level.

Hypothesis 3. There is no significant difference among the educational group with respect to economic, socio-cultural and environmental impact.

Table 7 explains the ANOVA for significant differences among educational groups with respect to economic, socio-cultural and environmental impact. As the $p$-value is less than $1 \%$ with respect to environmental impact, the null hypothesis is rejected at $1 \%$ level; it means that there are significant differences among educational qualification groups about environmental impact. There are no significant differences among educational qualification groups about economic and socio-cultural impact, as the $p$-value is more than $5 \%$. Hence, the null hypothesis is accepted for socio-cultural and economic impact.

Table 7. ANOVA for significant differences among educational groups with respect to economic, socio-cultural and environmental impact.

\begin{tabular}{|c|c|c|c|c|c|}
\hline Tourism Impact & Education & Mean & Std. Deviation & F-Value & $p$-Value \\
\hline \multirow{7}{*}{ Economic impact } & Diploma & 4.2350 & 0.51379 & \multirow{7}{*}{0.859} & \multirow{7}{*}{0.509} \\
\hline & Bachelor & 4.2119 & 0.51422 & & \\
\hline & Masters & 4.2564 & 0.48747 & & \\
\hline & Doctorate & 4.2500 & 0.51392 & & \\
\hline & $\begin{array}{l}\text { No formal } \\
\text { education }\end{array}$ & 3.5625 & 2.03293 & & \\
\hline & High school & 4.1295 & 0.62220 & & \\
\hline & Total & 4.2162 & 0.52906 & & \\
\hline \multirow{7}{*}{$\begin{array}{l}\text { Socio-cultural } \\
\text { impact }\end{array}$} & Diploma & 3.6071 & 0.68628 & \multirow{7}{*}{1.458} & \multirow{7}{*}{0.203} \\
\hline & Bachelor & 3.5760 & 0.60662 & & \\
\hline & Masters & 3.7949 & 0.87377 & & \\
\hline & Doctorate & 3.8080 & 0.79217 & & \\
\hline & $\begin{array}{l}\text { No formal } \\
\text { education }\end{array}$ & 3.6429 & 0.70711 & & \\
\hline & High school & 3.4643 & 0.69620 & & \\
\hline & Total & 3.6175 & 0.68295 & & \\
\hline
\end{tabular}


Table 7. Cont.

\begin{tabular}{|c|c|c|c|c|c|}
\hline Tourism Impact & Education & Mean & Std. Deviation & $F$-Value & $p$-Value \\
\hline \multirow{7}{*}{$\begin{array}{c}\text { Environmental } \\
\text { impact }\end{array}$} & Diploma & 3.6650 & 0.70253 & \multirow{7}{*}{5.090} & \multirow{7}{*}{$<0.001 *$} \\
\hline & Bachelor & 3.6150 & 0.55627 & & \\
\hline & Masters & 4.0641 & 0.57939 & & \\
\hline & Doctorate & 3.9427 & 0.72785 & & \\
\hline & $\begin{array}{l}\text { No formal } \\
\text { education }\end{array}$ & 4.0000 & 0.23570 & & \\
\hline & High school & 3.5298 & 0.51531 & & \\
\hline & Total & 3.6959 & 0.62740 & & \\
\hline
\end{tabular}

Source: Authors' Calculation (Primary data), * -Significant at 1\% level.

\section{Discussion}

The local community perceive a positive economic impact on tourism, and they perceive that tourism brings in new investment and creates new job opportunities. They also think that tourism provides opportunities to develop new local businesses as well as that tourism has increased the revenues of local people and the economy. As far as socio-cultural impact is concerned, residents think that tourism helps to preserve local cultural activities; they are able to meet people of different cultures and traditions, and tourism has improved the quality of life of the local community. However, on the negative side, locals believe that tourism destroys the local peaceful atmosphere, reduces the quality of the local environment and littering of wastes spoils the natural environment, water ways, etc. Our research results show significant differences among age groups which finds support from Almeida-Garcia et al. (2016), who also found significant differences in age with respect to environmental impact. It was concluded from our study that there are no significant differences among different genders with respect to socio-cultural and environmental impacts. These findings are in contrast to Swain (1995), who found that male and female respondents differ significantly in their perceptions on tourism development.

Local communities are also satisfied with the attention paid by the government to protect the environment. The study indicates that the local community is aware of the benefits of tourism development. The government should take steps to create awareness about the need for public support for the preservation of heritage sites. They should also be provided information about how the local community can benefit by way of job opportunities, small businesses, etc.

The COVID-19 pandemic has affected the tourism industry and ultimately resulted in greater loss to economic development. COVID-19 has not only created a negative impact on the tourism sector in the Middle East, but also around the globe due to travel-related bans. This is the time when residents' support is much needed for the revival of the tourism industry. Hence, future research should focus on the steps that can be taken to create awareness among the public for tourism development as well as to preserve the tourist sites.

Author Contributions: Conceptualization, A.R.; methodology, A.R.; software, A.R.; validation, A.R., S.A.S. and K.M.M.; formal analysis, A.R. investigation, K.M.M.; resources, A.R., S.A.S. and K.M.M.; data curation A.R.; writing-original draft preparation, A.R.; writing-review and editing, A.R.; visualization A.R.; supervision, A.R.; project administration, A.R.; funding acquisition, A.R., S.A.S. and K.M.M. All authors have read and agreed to the published version of the manuscript.

Funding: The research leading to these results has received Project Funding from The Research Council (T.R.C.) of the Sultanate of Oman under the Research Grant from Block Funding Program Agreement-2020 (MoHERI-BFP-UoTAS-HCT-01-2020).

Institutional Review Board Statement: Not applicable. 
Informed Consent Statement: Not applicable.

Conflicts of Interest: The authors declare no conflict of interest.

\section{Appendix A}

\section{Model Questionnaire}

1. Demographic profile of respondents

Age:

Gender:

Occupation:

Education:

Monthly income:

2. Tourism impact and environmental protection measures

\begin{tabular}{|c|c|}
\hline S. No & Questions \\
\hline 1 & Tourism creates new job opportunities \\
\hline 2 & Tourism provides opportunities to develop new businesses \\
\hline 3 & Tourism brings in more investment \\
\hline 4 & Tourism has increased revenues of local people \\
\hline 5 & Tourism has created more infrastructural facilities \\
\hline 6 & Places in Oman attract many foreign tourists \\
\hline 7 & $\begin{array}{c}\text { Tourism has provided an incentive for the restoration of historical and traditional } \\
\text { buildings }\end{array}$ \\
\hline 8 & Tourism has created better image of the country among the foreigners \\
\hline 9 & Tourism helps to preserve local cultural activities \\
\hline 10 & Able to meet people of different cultures and traditions \\
\hline 11 & Tourism causes change in the traditional culture among the local people \\
\hline 12 & Tourism development interferes with the daily life of local residents \\
\hline 13 & Tourism has improved the quality of life of local community \\
\hline 14 & Tourism increases the quality of education \\
\hline 15 & Tourism development leads to a rise in domestic waste. \\
\hline 16 & Tourism development reduces the quality of the local environment \\
\hline 17 & Littering of wastes spoils the natural environment, water ways, etc. \\
\hline 18 & Tourism increases air pollution \\
\hline 19 & Tourism positively influences environmental awareness among locals \\
\hline 20 & Government pays good attention to protect environment in Oman \\
\hline 21 & $\begin{array}{l}\text { Public places have information and guidance for visitors regarding environmental } \\
\text { protection }\end{array}$ \\
\hline 22 & Fines are applied to those who harm the environment \\
\hline
\end{tabular}

\section{References}

Al-Hashim, Alya. 2015. Embracing Sustainable Tourism in Oman: Case Study of Mirbat Settlement. International Journal of Cultural and Digital Tourism 2: 8-16.

Al-Hasni, Zakiya Salim. 2021. The Economic Impact of COVID-19 on the Omani Tourism Sector. Psychology and Education 58: 824-30. [CrossRef]

Almeida-Garcia, Fernando, Pelaez-Fernandez María Ángeles, Cortés-Macias Rafael, and Balbuena-Vazquez Antonia. 2016. Residents' Perceptions of Tourism Development in Benalmadena, Tourism Management. Available online: https://riuma.uma.es/xmlui/ bitstream/handle/10630/10718/PREPRINT.pdf?sequence=3 (accessed on 25 May 2021). [CrossRef] 
Ap, John. 1992. Residents' Perceptions of Tourism Impacts. Annals of Tourism Research 19: 665-90. [CrossRef]

Ap, John, and John Crompton. 1998. Developing and Testing a Tourism Impact Scale. Journal of Travel Research 37: 120-30. [CrossRef]

Bakshi, Shuchita, and Deepak Raj Gupta. 2016. Evaluating Local Resident's Perception \& Participation in Community Based Tourism Development: A Case Study of Jammu Region. International Journal of Hospitality E Tourism Systems 9: 26-37.

Baporikar, Neeta. 2012. Emerging Trends in Tourism Industry in Oman. In Global Hospitality and Tourism Management Technologies. Hershey: IGI Global, pp. 116-35.

Chandralal, Lalith. 2010. Impacts of Tourism and Community Attitude towards Tourism: A Case Study in Sri Lanka. South Asian Journal of Tourism and Heritage 3: 41-49.

Cooke, Karen. 1982. Guidelines for Socially Appropriate Tourism Development in British Columbia. Journal of Travel Research 21: $22-28$. [CrossRef]

Davis, Duane, Jeff Allen, and Robert Cosenza. 1988. Segmenting Local Residents by Their Attitudes, Interests, and Opinions toward Tourism. Journal of Travel Research 27: 2-8. [CrossRef]

Delamere, Thomas Arthur. 1998. Development of a Scale to Measure Local Resident Attitudes toward the Social Impact of Community Festivals. Unpublished Ph.D. dissertation, University of Alberta, Edmonton, AB, Canada.

Dola, Kamariah, and Mijan Dolbani. 2006. Public Participation in Planning for Sustainable Development: Operational Questions and Issues. International Journal on Sustainable Tropical Design Research E Practice 1: 1-8.

Eshliki, Sajad Alipour, and Kaboudi Mahdi. 2012. Community Perception of Tourism Impacts and Their Participation in Tourism Planning: A Case Study of Ramsar, Iran. SEAN Conference on Environment-Behaviour Studies. Bandung: Elsevier B.V., pp. 333-41.

Godfrey, Kerry. 1998. Attitudes towards Sustainable Tourism in the UK: A View from Local Government. Tourism Management 19: 213-24. [CrossRef]

Gunn, Clare. 1994. Tourism Planning: Basics, Concepts, Cases, 3rd ed. Washington, DC: Taylor and Francis.

Hair, Joseph, Black William, Babin Barry, and Anderson Rolph. 2010. Multivariate Data Analysis: A Global Perspective. Hoboken: Pearson Prentice Hall.

Hall, Colin Michael. 1994. Tourism and Politics: Policy, Power, and Place. Chichester: Wiley.

Healey, P. 1998. Building Institutional Capacity through Collaborative Approaches to Urban Planning. Environment and Planning 30: 1531-46. [CrossRef]

Hilsenrath, Jon. 2020. Global viral outbreaks like coronavirus, once rare, will become more common. The Wall Street Journal. Available online: https:/ / www.wsj.com/articles/viral-outbreaks-once-rare-become-part-of-the-global-landscape-11583455309 (accessed on 30 May 2021).

Jamal, Tazim, and Donald Getz. 1995. Collaboration Theory and Community Tourism Planning. Annals of Tourism Research 22: 186-204. [CrossRef]

Jamieson, Walter, and Tazim Jamal. 1997. Tourism Planning and Destination Management. In International Tourism: A Global Perspective. Edited by C. Gee and E. Fayos-Sola. Madrid: World Tourism Organization, pp. 321-37.

Joppe, Marion. 1996. Sustainable Community Tourism Development Revisited. Tourism Management 17: 475-79. [CrossRef]

Kandampully, Jay. 2000. The Impact of Demand Fluctuation on the Quality of Service: A Tourism Industry Example. Managing Service Quality 10: 10-18. [CrossRef]

Kaplan, S. 2015. Community involvement and sustainability of tourism: A discussion through local community understanding in the eastern black sea region. WIT Transactions on Ecology and The Environment 193: 885-94.

Kutty, Samuel. 2021. Sultanate of Oman Among Top Countries to Visit in 2022. Available online: https://www.omanobserver.om/ article/1111656/oman/tourism/sultanate-of-oman-among-top-countries-to-visit-in-2022 (accessed on 25 December 2021).

Lindberg, Kreg, and Johnson Rebecca. 1997. The economic values of tourism's social impacts. Annals of Tourism Research 24: 90-116. [CrossRef]

McIntyre, George, Hetherington Arlene, and Inskeep Edward. 1993. Sustainable Tourism Development: Guide for Local Planners. Madrid: World Tourism Organization.

Mershen, Birgit. 2007. Development of Community-Based Tourism in Oman: Challenges and Opportunities. In Tourism in the Middle East. Edited by R. Daher. Clevedon: Channel View, pp. 188-214.

Murphy, Peter. 1985. Tourism: A Community Approach. New York: Methuen.

Prabhu, Conrad. 2015. Homeport is Key to Oman's Cruise Tourism Industry. Interview with: Jose, M.C., CEO of Khimji Ramdas Shipping. Oman Daily Observer. Available online: https:/ / www.pressreader.com/oman/oman-daily-observer/20150630/28227 8138986824 (accessed on 25 December 2020).

Rasoolimanesh, Mostafa, and Jaafar Mastura. 2016. Community Participation toward Tourism Development and Conservation Program in Rural World Heritage Sites. Available online: https://www.researchgate.net/publication/292857496_Community_ Participation_toward_Tourism_Development_and_Conservation_Program_in_Rural_World_Heritage_Sites (accessed on 6 December 2021)

Sharpley, Richard. 2000. Tourism and Sustainable Development: Exploring the Theoretical Divide. Journal of Sustainable Tourism 8: 1-19. [CrossRef]

Sirakaya, Ercan. 1997. Attitudinal Compliance with Ecotourism Guidelines. Annals of Tourism Research 24: 919-50. [CrossRef]

Sirakaya, Ercan, Tazim Jamal, and Hwan-Suk Choi. 2001. Developing Indicators for Destination Sustainability. In The Encyclopedia of Ecotourism. Edited by D. B. Weaver. New York: CAB International, pp. 411-32. 
Sirakaya, Ercan, Yusel Ekinci, and Alp Kaya. 2008. An Examination of the Validity of SUS-TAS in Cross-Cultures. Journal of Travel Research 46: 414-21. [CrossRef]

Stefanica, Mirela, and Gina Ionela Butnaru. 2015. Research on tourists' perception of the relationship between tourism and environment. Procedia Economics and Finance 20: 595-600. [CrossRef]

Swain, M. B. 1995. Gender in Tourism. Annals of Tourism Research 22: 247-66. [CrossRef]

Oman Tourism. 2015. Focus on Sustainable tourism industry in Oman, Travel to Oman, Ministry of Tourism, Sultanate of Oman. Available online: https://www.omantourism.gov.om/wps/portal/mot/tourism/oman/details/!ut/p/a0/04 (accessed on 27 November 2021).

Tsaur, Hshiung-Sheng, and Chih-Hung Wang. 2007. The Evaluation of Sustainable Tourism Development by Analytic Hierarchy Process and Fuzzy Set Theory: An Empirical Study on the Green Island in Taiwan. Asia Pacific Journal of Tourism Research 12: 127-45. [CrossRef]

UNWTO. 2020. Sustainable Development. Available online: https://wwwm.unwto.org/sustainable-development (accessed on 5 November 2021).

UNWTO. 2021. Tourism for Inclusive Growth. Available online: https:/ /www.unwto.org/wtd2021 (accessed on 27 November 2021). 